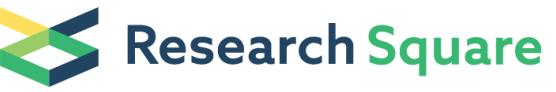 \\ Preprints are preliminary reports that have not undergone peer review. \\ They should not be considered conclusive, used to inform clinical practice, or referenced by the media as validated information.
}

\section{PML-II regulates ERK and AKT signal activation and IFNa-induced cell death}

\section{Xueqiong Meng \\ Yixiang Chen \\ Salvador Macip \\ Keith Leppard}

\section{Video Byte}

Keywords: promyelocytic leukemia protein, PML-II, IFNa, apoptotic signaling, ERK, AKT, cell death, apoptosis, interferon, IFN, promyelocytic leukaemia protein, type I interferon, type I IFN, HeLa cells, siRNA, tumor suppressor, pathogen response, damage response, gene silencing, cancer pathway, cancer signaling, anticancer, antitumor, tumorigenesis, Cell Communication and Signaling

Posted Date: October 13th, 2021

DOI: https://doi.org/10.21203/rs.3.rs-966255/v1

License: (c) (i) This work is licensed under a Creative Commons Attribution 4.0 International License. Read Full License 


\section{Abstract}

The protein IFNa can reduce growth and promote apoptosis of cancer cells by stimulating genes such as $P M L$, whose deficiency is linked to tumorigenesis, but the contributions of different PML isoforms to the anticancer effects remain unclear. Given that PML-II positively regulates genes that are induced during the type I IFN response, researchers recently investigated whether and how PML-II participates in IFNainduced cell death using a cervical cancer cell line. In cells with PML-II deletion (siPML-II), death during IFNa stimulation was reduced, and IFNa-induced ISG54 mRNA expression was attenuated. In addition, silencing PML-II decreased the expression of TRAIL and PUMA during IFNa stimulation, indicating that the extrinsic and intrinsic apoptosis pathways were blunted. In contrast, the prosurvival ERK and AKT pathways were activated, suggesting that PML-II suppresses these pathways under normal conditions, and the enhanced AKT pathway activation during IFNa stimulation likely helped the cells resist IFNainduced death. Although further research is needed to reveal the exact mechanisms and mediators, the results account for some of PML's tumor-suppressing effects and explain why PML deficiency is linked to apoptosis resistance. 